\title{
PARIA, THE SOUTHERN INKA CAPITAL REDISCOVERED
}

\author{
PARIA, LA CAPITAL INKA DEL SUR REDESCUBIERTA
}

\author{
Martti Pärssinen ${ }^{1}$, Risto Kesseli ${ }^{2}$ y Juan Faldín ${ }^{3}$
}

Early historical sources mention Paria as one of the most important provincial settlements in the Inka State. Being such an important settlement, the first Spanish village in southern part of former Tawantinsuyu, was decided to establish in Paria. The foundation was ordered by Diego Almagro in 1535. Nevertheless, it has been somewhat of mystery for archaeologists how faraway the Spaniards moved the new foundation from the original Paria, so admired by the Inkas, because no Inka artifacts have been found in the Colonial foundation. In many occasions John V. Murra also wondered about the location of the original Paria. In 1960 Hermann Trimborn had identified old Paria, Paria la Vieja, as a place situated some distance towards the north of the present Paria. Nevertheless, John Hyslop put forward the idea that Paria was the same as Anocariri, situated to the west-northwest of the present Paria. Some Inka researchers accepted Hyslop's identification, but also doubts have been presented. Quite recently the team of Carola Condarco Castellón returned to Trimborn's idea and inspected the area belonging to the village of Pulupampa, situated to northwest of Obrajes and actually found there a settlement with Inka ceramics. This is why they reported that "Paria la India" or "Paria la Vieja" was found. Nevertheless, they did not inform either marks of huge administrative compounds or any concentration of silos. In 2004 we decided to visit Paria in order to make an independent identification of the exact site of the Inka southern capital using archival sources and our archaeological experiences in these kinds of multidisciplinary enterprises. As a result, we may conclude that the earlier identification of Paria la Vieja, as proposed by Trimborn and the team of Carola Condarco, is correct. Comparing to the archaeological evidence of Anocariri site, proposed to be Paria la Vieja by John Hyslop, our site is three times bigger (35 ha vs 100 ha). Furthermore, the ceramic assemblage of our site in Pulupampa is predominantly composed of the Inka and the Regional Inka varieties unlike Anocariri, and finally, new evidence published in this report demonstrates that our site is the only one that has a huge concentration of storehouses. We were able to identify quite exactly 1,000 silos and various foundations of huge administrative buildings.

Key words: Paria, Inka settlements, Colonial settlements, archaeology, history, storehouses.

Fuentes primitivas mencionan ya a Paria como uno de los establecimientos provinciales más importantes del Estado inka. Al ser un asentamiento tan importante, el primer pueblo español de la parte sur de lo que era Tawantinsuyu, se decidió que se estableciera en Paria. Su fundación fue ordenada por Diego Almagro en 1535. Sin embargo, supone un misterio para los arqueólogos lo lejos que movieron los españoles esta nueva fundación de lo que era la ciudad de Paria original, tan admirada por los inkas, ya que no se han encontrado restos inkas en la fundación Colonial. En muchas ocasiones John V. Murra también se preguntó sobre la localización original Paria. En 1960 Hermann Trimborn había identificado a la antigua Paria, Paria la Vieja, como un lugar situado hacia el Norte de la ciudad actual. No obstante, John Hyslop propuso la idea de que Paria era lo mismo que Anocariri, situada al noroeste de de la ciudad actual. Algunos investigadores inkas han aceptado la identificación de Hyslop, aunque también se han presentado algunas dudas al respecto.

Recientemente el equipo de Carola Condarco Castellón ha vuelto a la idea de Trimborn y ha inspeccionado el área que pertenece al pueblo de Pulupampa, situado al noroeste de Obrajes, y encontró allí un asentamiento con cerámica inka. Esta es la razón por la que se informó que "Paria la india" o "Paria la vieja" había sido encontrada. No obstante, no constan marcas de complejos administrativos o concentraciones de silos. En 2004 decidimos visitar Paria con el fin de realizar una identificación independiente de la localización exacta de la capital sureña Inka, usando fuentes documentales y nuestra experiencia arqueológica en este tipo de empresas multidisciplinarias. Como resultado, podemos concluir que la identificación anterior de Paria la vieja, tal y como fue propuesta por Trimborn y el equipo de Carola Condarco, es correcta. Comparada con la evidencia arqueológica de la localización de Anocariri, la propuesta de John Hyslop para Paria la Vieja, muestra localización es tres veces más grande (100 hectáreas, contra las 35 ha. de la anterior). Además, el ensamblaje cerámico de nuestra localización en Pulupampa está compuesto predominantemente de las variedades Inkas e Inka Regionales, no como Anocariri, y finalmente, una nueva evidencia publicada en este informe demuestra que nuestra localización es la única que tiene una gran concentración de almacenes. Fuimos capaces de identificar cerca de 1.000 silos y varias fundaciones de enormes edificios administrativos.

Palabras claves: Paria, asentamientos inkas, asentamientos coloniales, arqueología, historia, silos.

\footnotetext{
1 Instituto Iberoamericano de Finlandia, C. General Arrando 5, E-28010 Madrid, España. martti.parssinen@madrid.fi

2 Department of Archaeology, P.O. Box 59, FI-00014 University of Helsinki, Finlandia. risto.kesseli@ helsinki.fi

3 Unidad Nacional de Arqueología de Bolivia, C. Tiwanaku 93, La Paz, Bolivia. juanfaldin@ hotmail.com
} 
According to Guaman Poma de Ayala (1987 [1615]:185) the Inka ordered that there should be other Cuzco (the Inka capital) in Quito, Tumi[pampa], Huánuco [Pampa], Hatun Colla and one in Charcas. The list is probably not complete, but what is important here is the fact that from other sources we know that the capital of Charcas was Paria, a place where soldiers of Charcas confederation met before they marched to Cuzco and further on toward north, in order to participate in the military campaigns on the northern frontiers of the Inka Empire (Ayavire y Velasco et al. 1969 [1582]:25; see also Hyslop 1990:303-304; Pärssinen 1992:267; Morris and Thompson 1985:32; Murra et. al. 1987:1327 note 187:2). Also Cieza de León (1986a [1553 I:xlii]:137) mentions Paria as a place of highest regard among the Inkas along with Quito, Tomepampa, Cajamarca, Jauja and Vilcas. He also explains that the Inkas (especially Topa Inka) ordered the building of many storehouses, lodgings and a sun temple over there (Cieza de León 1553 I:cvi, 1986a:286; 1986b [1553 II:lxi]:177). This information is partially confirmed by local witnesses interviewed in Cochabamba in the mid $16^{\text {th }}$ century. In the documents published by Adolfo de Morales (1977) and Nathan Wachtel (1982), it was testified that the crop of corn production of Cochabamba Valley, organized by Huayna Capac, was transported first to Paria and from there to Cuzco by llama caravans (see also La Lone and La Lone 1987:50-51) ${ }^{1}$.

\section{The Spanish Foundation of Paria and the Search of its Original Site}

Being such an important settlement, the first Spanish village in southern part of the former Inka State, Tawantinsuyu, was decided to establish in Paria. The foundation was ordered by Diego Almagro, after he made an agreement with Francisco Pizarro over his governance of Collao, Charcas and Chile in the southern part of the empire. For that purpose he sent his captain Juan de Saavedra together with Paulo Inga, Vilaoma, 150 Spaniards and several hundred Indians, to make the foundation for a new Spanish village in Paria, which they did on July 15, 1535 (Barragán Vargas 2001:19). Soon Almagro also arrived in Paria. From there Almagro continued his journey to Tupiza (situated in southern Bolivia), where Paulo Inga and Vilaoma were already waiting for him in order to secure the Spanish "conquest" of Chile (Segovia 1943 [1552]:55). Since then Paria has been an important crossing point on the main road between the southern and central Andes ${ }^{2}$.

Nevertheless, it has somewhat of mystery for archaeologists how far-away the Spaniards moved (reduced) the new foundation from the original Paria, so admired by the Inkas, because no Inka artifacts have been found in the Colonial Paria. In 1960 Hermann Trimborn identified old Paria, Paria la Viaja, as a place situated some distance "toward the north of the present Paria," and some distance "toward the northwest of the hot springs of Obrajes" (Trimborn 1967:61-62). Nevertheless, his site description was not very accurate and he also claimed that no traces of Inkan Sun Temple or storage facilities could be seen there. Thus, John Hyslop (1984:145) interpreted that Trimborn had been referring to a little Khota Chullpa site situated northeast from Obrajes. Hyslop interpreted further that the site is too small to be Paria la Vieja and put forward the idea that Paria was the same as Anocariri, situated, according to him, ca. 8 kilometers to the west-northwest of the present Paria (Hyslop 1984:143-145). The site has ca. 35 hectares. Nevertheless, most of the sherds collected were unidentified varieties and only few Inka or Inka-influenced and Colonial fragments were found. Some tapia walls with rooms and rectangular or square enclosures were observed, but no Sun Temple or qollkas (silos) were found either (Hyslop 1984).

Some Inka researchers have accepted Hyslop's identification (e.g. Jenkins 2001:665), but also doubts have been presented (e.g. Raffino 1993:203-204). In many occasions John V. Murra also wondered about the location of the original Paria. Quite recently Carola Condarco Castellón, Edgar Huarachi Mamani and Mile J. Vargas Rosquellas (2002) returned to Trimborn's idea and inspected the area belonging to the village of Pulupampa, situated to northwest of Obrajes and actually found there a settlement of at least 50 hectares with Inka, Inkaregional and local ceramics styles. This is why they reported that "Paria la India" or "Paria la Vieja" was found. Nevertheless, they found neither the mark of Sun Temple nor silos for the corn of Cochabamba (Condarco et al. 2002:82). For this reason we did not know whether or not they were right.

\section{Clues of history}

In 2004, during the Finnish-Bolivian research project Formations and transformations of ethnic 
identities in the South Central Andes, AD 700-1825 we conducted field research on the Pariti Island (Korpisaari and Pärssinen 2005), but also in ancient Aymara provinces of Pacasa, Caranga, Quillaga, Caracara, Charca y Sora identifying chullpa towers and ancient settlements mentioned in Inkan and Colonial khipu text, transcribed and translated in the $16^{\text {th }}$ century by Spanish State officials (see Pärssinen and Kiviharju 2004:50-55, 385-419). As a part of the project we decided to visit Paria in order to make an independent identification of the exact site of the Inka southern capital using archival sources and our archaeological experiences in these kinds of multidisciplinary enterprises (for more details, see Pärssinen 1997).

During our archival research it appeared that the province of Sora was divided into four quarters with their respective main towns: Paria, Tapacari, Capinota and Caracollo (see also Del Río 1997:3132). Of these, Caracollo and Paria were situated on the main Inka road at one-day's walking distance, serving as tampu stations with roadside lodgings and storage facilities (Vaca de Castro 1908 [1543]:435). Furthermore, we observed that in a khipu census, copied in the title of the encomienda grant of Francisco Pizarro to Alonso de Manjarres, one of the biggest village of Sora in the Caracollo quarter of Sora province was called Apacomire (Pizarro 1540: fol. 13r.). For us it seemed that Hyslop's Anocariri was probably the same as Apacomire in our document, since other facts such as its size and probable place in Caracollo sector also correspond quite well with the historical information. Thus, it is not likely that Anocariri was the same as Paria la Vieja. Nor did Hyslop's archaeological evidence support other fact that Anocariri was a local village with considerable large size.

Already in the title of encomienda given to Alonso Manjarres, the distance of few villages of Paria is mentioned. Nevertheless, during our archival investigation it appeared that probably the best source to identify ancient Paria was another document with a list of sacred lines or ceques of Paria and Capinota. This document titled as "Los moxones e limites de las tierras que dio el ynga Guayna Capa a los yndios soras de Paria la viexa." is conserved in the Historical Archive of Cochabamba, and is written in the year 1593, but it appears to be a copy of an older undated original. We are grateful to John V. Murra for informing us of this document and for lending us his own transcription. Quite recently
Mercedes del Río (1997:52-56) has demonstrated that the lines mentioned in the list were originally established by an Inka official called Casir Capac, who, as mentioned by Pachacuti Yamqui (1993 [1613]:238), was a general visitador of agricultural and herding lands. This same man was said to establish the ceques of Paria and Capinota at the time of Huayna Capac, totalling 41 as the famous ceques of Cuzco (e.g. Bauer 2000; Pärssinen and Kiviharju 2004:101-102; Zuidema 1995). What is important in the document is the fact that the distances of various sites were systematically established from the point of view Paria la Vieja and Capinota, two of the four principal towns of Sora province.

The document demonstrates that the town of Paria was situated only 1 league (ca. 5-6 km) from the lands of Tapacari in northeast; from 2 to 3 leagues from the lands of Caracollo in northwest; and 1.5 leagues of the lands of Capinota in southeast; while the main territory of Paria extended toward the Lake Popoó in the south and southwest. Furthermore, according to the same document, Torchinoca, the nearest settlement of Paria quarter of Sora on the shores of the northern Lake Poopó (Lake Uru Uru), was situated in a distance of 5 leagues (ca. $28 \mathrm{~km}$ ) of Paria la Vieja (Anónimo 1593: fols 1r. -11v.). Finally, by bringing together this kind of historical information we were able to draw a circular area of ca. 12 kilometers in diameter inside which old Paria should be located.

\section{Archaeological rediscovery}

We started our actual search of Paria on the morning of June 29, 2004 by $4 \times 4$ vehicle. First we went to the extreme northeast sector of our circle to the site called Estancia Conchiri. From there (in the eastern side of Cerro Jankho Khalani) we found an Inka style kallanka that measures 27.10 x 5.30 meters. The southern end of the building is still 2.15 meters high of which the first 150 centimeters are of a stone structure and the upper part is made of mud (tapia). We collected some Inka, Inka Regional and Local style sherds, and we also observed various adobe chullpa towers nearby, but we concluded that the site is too small to be Paria.

After Conchiri, we drove to northwest and further to the southwest and southeast of our circle with no good results. Nevertheless, we had a good opportunity to observe our research area from different angles and our attention was driven to a 
natural terrace-like formation inside of our research circle, situated some one and a half kilometers north of the hot springs of Obrajes. Because we observed there a clear variation in the color and thickness of $i c h u$ vegetation there we decided to investigate the area more closely. On arriving there, after a four hour search, we immediately noticed a huge concentration of Inka style ceramic sherds. We left our car and walked the area with ca. lines of 200 meters sampling archaeological material. It appeared that the site is comprised of ca. 100 hectares in total. Part of the structures in the southeastern part of the settlement has been fallen into the river Jacha Uma. In the southwest the site is limited on a low natural terrace, and in the north and east the site is limited by a small dale with a spring (Figures 1-2). During our inspection we observed basements of some so called kallanka barracks, various huge quadrangular enclosures, plazas, circular structures of ca. 5 meters in diameter, etc., but all structures have fallen down because most of the walls seem to have been made of adobe and small stones. It is possible that some buildings would originally have had pure stone walls, but even if so, the stones were transported away from the ruined site and reused in a similar fashion as Julien (1983:89-90) has documented in Hatun Colla $^{3}$. However, what was the most decisive for our identification was the discovery of ca. 1,000 stone foundations of Inka qollka structures, round storehouses in eleven lines in the northern part of the site (Figures 3-4).

For us there was no doubt we were in ancient Paria. After returning to La Paz, we checked the earlier identification of Trimborn and the team of Condarco: it appeared that they have identified the same site as we did, but somehow both of them had failed to walk whole area and thus they had missed the huge deposit capacity of the site. Also Hyslop had passed through the area, but even he had missed the crucial evidence.

Foundations of the inspected silos are low, but still well visible. Silos are made of natural stones by so called pirca-technique although it is probable, that the upper walls of these storage structures were built of adobe. Anyhow, each of them was ca. 3 meters in diameter and those were arranged in rows in west-east orientation. In general, silos of Paria are quite similar to those we know in Cochabamba, Chuquisaca and Salta (Cespedes Paz 1982:95-97; Pereira Herrera 1982:101-104; Pärssinen and
Siiriäinen 1998:150-151, 2003:182-183; Snead 1992:92-93).

Judging by the amount of the storehouses, it appears that in Cotapachi (Cochabamba) and Campo del Pucara (Salta) there are more storage structures than in Paria (Gasparini and Margolies 1980:303; Jenkins 2001:table 1; Snead 1992:9293). Nevertheless, those two rural sites are not administrative centers, and if compared to storage facilities of other first order provincial centers such as Paria, we may note that only in Hatun Jauja one has documented more than a thousand (1069) silos attributed directly to the big administrative compound (D'Altroy 1992:169, 2002:281; Snead 1992:table 3-1.). In Vilcas there may have been some 700 qollka, but even in Huánuco Pampa (497) and Pumpu (589) both have fewer structures (Morris and Thompson 1974:200: Matos Mendieta 1994:255; see also Alconini 2004:table 4). Thus, the storage capacity of Paria is just what should be expected for such an important centre situated in the crossroad between Cochabamba and the southern Inka main roads.

Although we did not inspect the Inka road system in Paria, in an aerial photograph taken by Instituto Geográfico Militar in August 26, 1961 (1209B) a possible ancient road coming from Caracollo to the storage area of the settlement can be seen. Curiously, from the same storage area another ancient road directed toward the kallanka, we located in the northern part of Estancia Conchiri. It is likely to be connected with the mentioned, but archaeologically unidentified Tapacarí - Quilca road in the north. Furthermore, another road, inspected by Hyslop (1984:138-149), seem to have passed the settlement toward the east, to Tapacarí (and Capinota?), and finally the road to the south seems to have passed the hot springs of Obrajes and continued from there to Chayanta (Bouysse-Cassagne 1986: fig. 12.5.).

It is notable that in the storehouse area only few sherds were found. Those were pieces of aryballoid potteries generally associated with the storage of maize (D'Altroy 1992:174; Morris 1981:333). Furthermore, the amount of ceramic evidence was also quite limited toward southwest of the storage complex, and in fact, the densest concentration of ceramics was found in the area of 30 ha situated in the south, where one can still observe foundations of various huge buildings (Figure 2). In the same area the team of Carola Condarco had made 


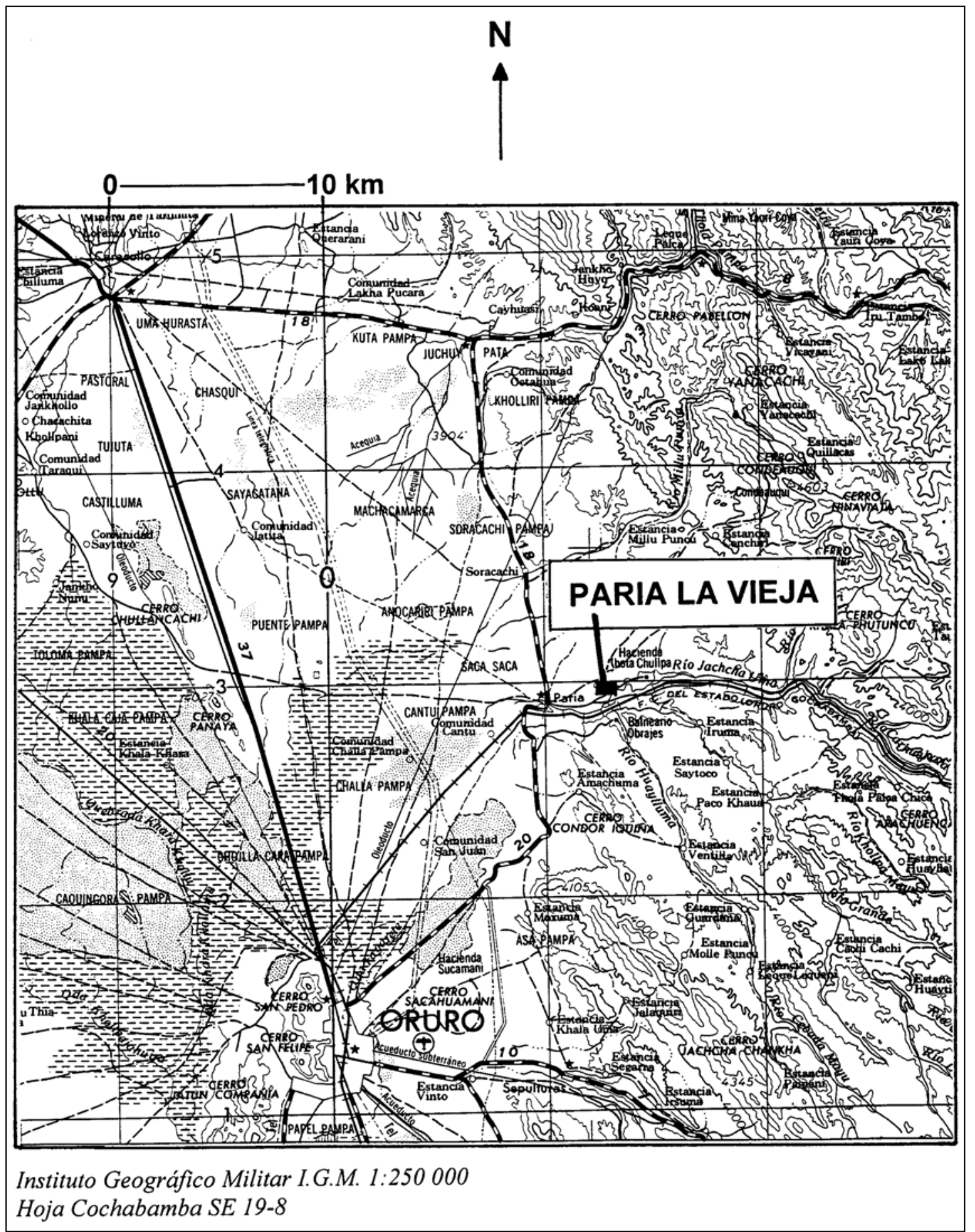

Figure 1. Location of Paria la Vieja.

Ubicación de Paria la Vieja. 


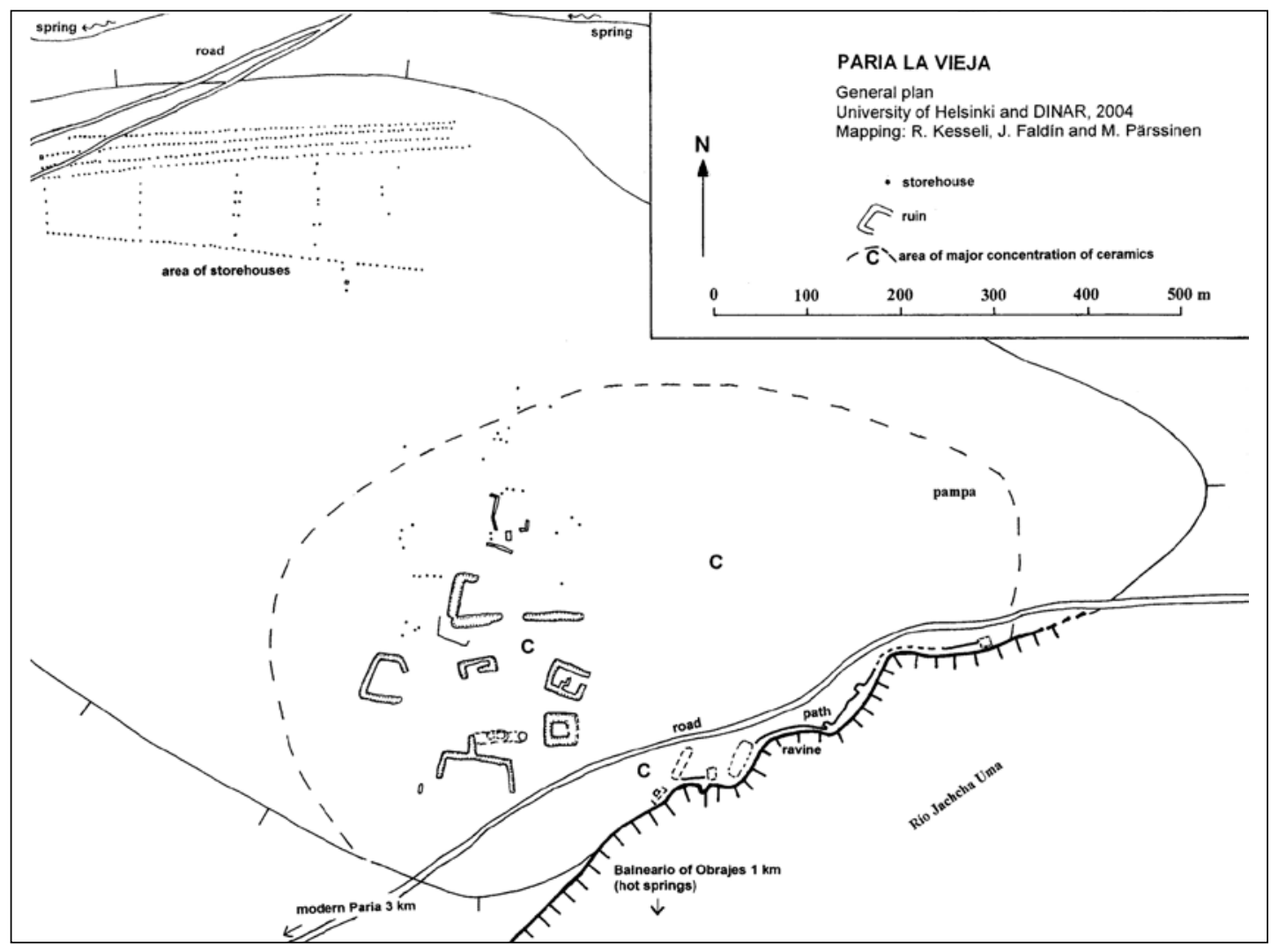

Figure 2. General plan of Paria la Vieja.

Plano general de Paria la Vieja.

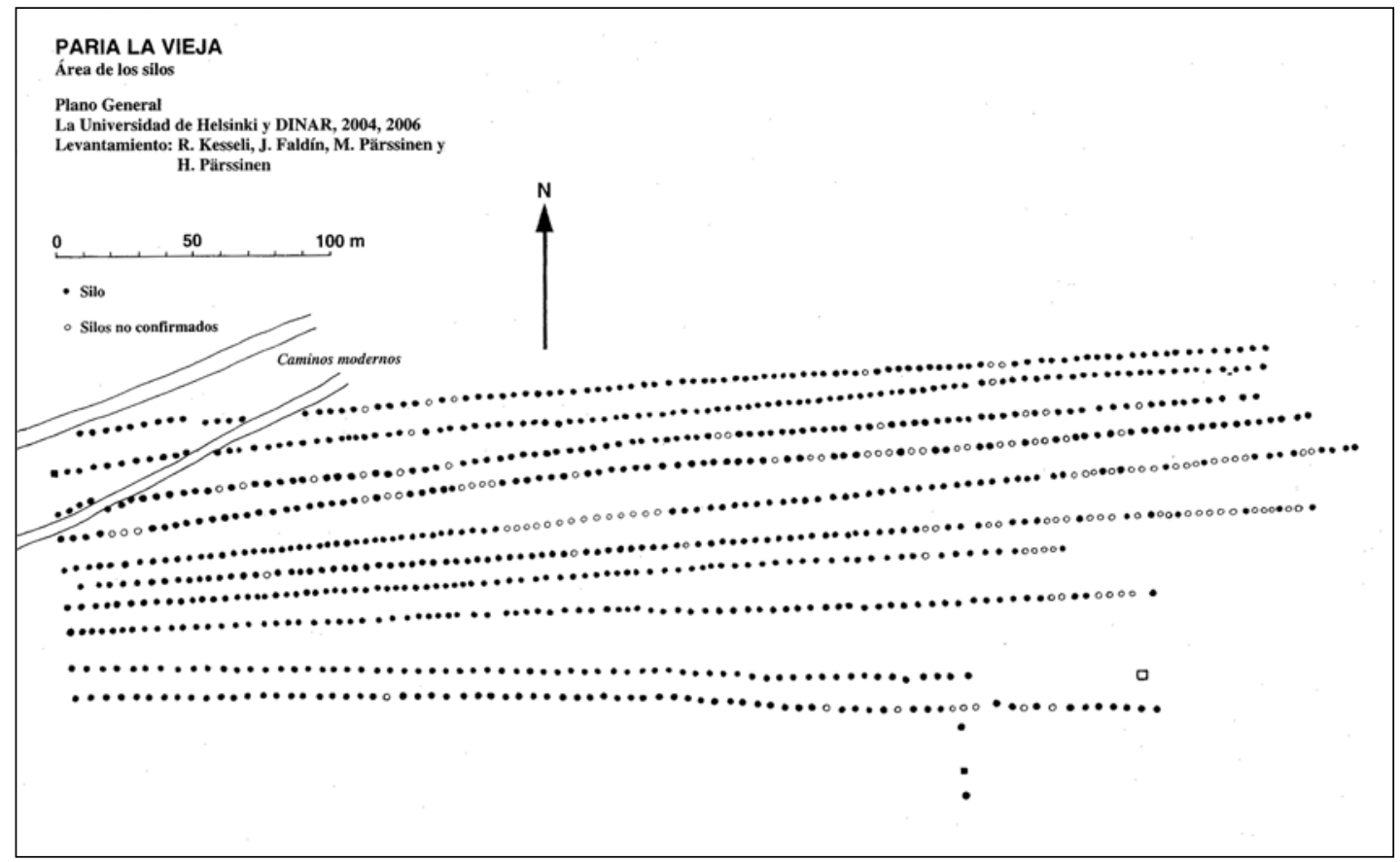

Figure 3. General plan of the storehouses in Paria la Vieja.

Plano general de los silos en Paria la Vieja. 


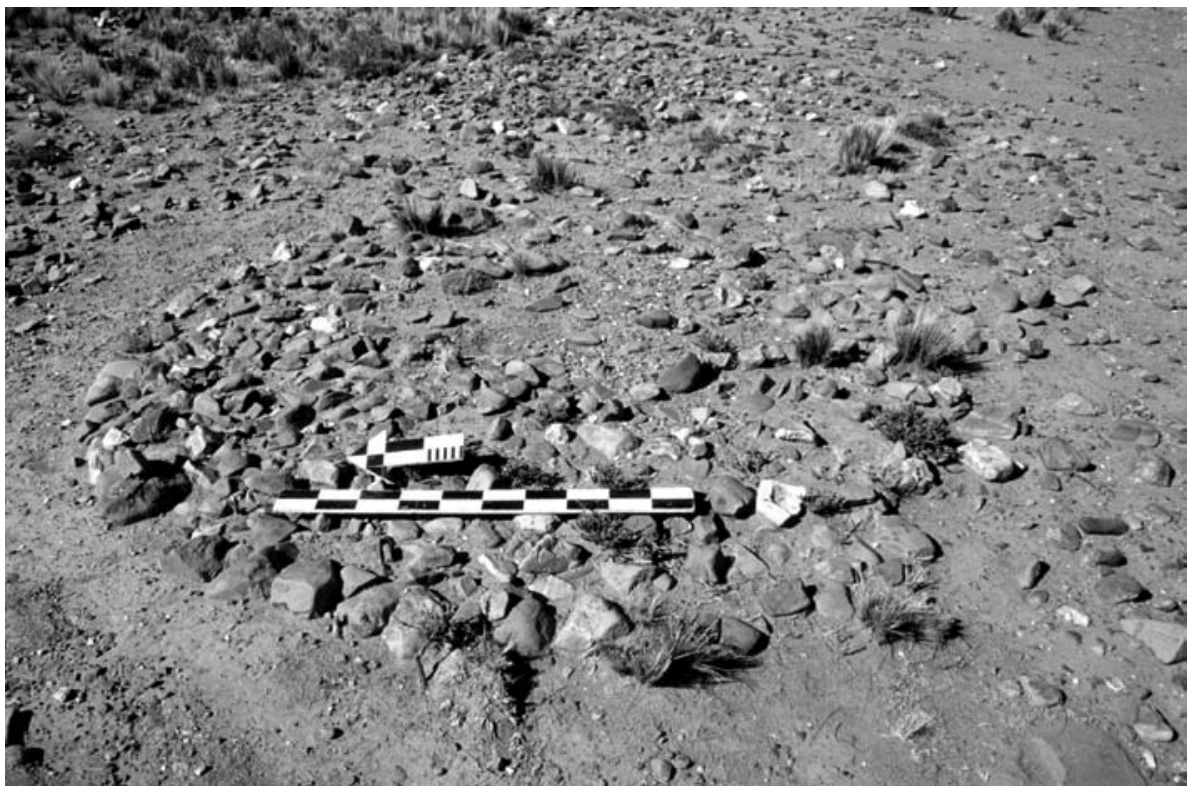

Figure 4. Photo of a typical stone foundation of the storehouses in Paria la Vieja.

Piedra base típica de los silos en Paria la Vieja.

some test excavation inside several structures they considered to be ritualistic buildings and domestic dwellings (Condarco et al. 2002:47-71). Because they found both local and Inka style ceramics they concluded that the site was already founded before the Inka time, but the site grew during the Inka period (Condarco et al. 2002:48, 82).

In general, during our own inspection 498 sherds were collected of which $68 \%$ can be classified into polychrome and bicolor Inka and Inka regional styles (Figure 6). As in many other southern areas (e.g. Covey 2000:126, 128), most of them were from aryballoid vessels, bowls and plates. Of the Inka regional varieties $6 \%$ belong to the Inka Pacajes style abundant in Pacasa province (Pärssinen 2005:passim; Figure 6F). Furthermore, judging by the paste, even most of the Inka ceramics of Cuzco Imperial style seem to be provincial production similar to InkaPacajes plates manufactured in the southern Lake Titicaca area. This is in agreement with a model of regionally focused production and distribution proposed earlier by Terence D'Altroy and Ronald Bishop (1990). Nevertheless, some white kaolin plates and small aryballus with yellowish paste were probably of Cuzco or Northern and Northwestern Lake Titicaca import (e.g. Tschopik 1946:passim; Julien 1993:190-199; D'Altroy et al. 2000:21). About $20 \%$ of sherds can be classified into Black-on-Red horizon style, general in Bolivian altiplano during the Late Intermediate and Late Horizon, and which may include some Inka bicolor sherds, while 5\% cannot be classified more exactly. Only $5 \%$ belongs to local Sora Dark Chestnut Brown-on-Brown style (Figure 5C), which can be distinguished especially by the wide brush painting on light brown background, or sometimes narrower line painting on slipped violet background. Furthermore, the ceramic paste is generally fired at a lower temperature than Inka ceramics, and one can still observe white quartz and mica inclusions in it with the naked eye. This style is typical in the sites like Sora Sora and Ch'usaqueri near Oruro, although we also have found similar pieces in Quillaca and Caracara provinces, too (own observation in 1989 and 2004). One percent of our sample represents Caranga (Figure 5A) and Pacajes styles (Figure 5D), and another $1 \%$ are Colonial sherds (indicating early abandonment of the site in Colonial Period). It is also worth mentioning that one dish sherd recovered in Paria la Vieja is decorated with incised serpent motifs and belongs to the style we have currently classified as Amazonian serpent style, common in Las Piedras, in an Inka fortress situated in the Confluence area of Beni and Madre de Díos, near Bolivian and Brasilian border zone (Pärssinen and Siiriäinen 2003:115; Siiriäinen and Pärssinen 2003:66). As in Las Piedras, the pottery fragment of Paria had caripé charcoal in its clay mixture (Figure 5E). 


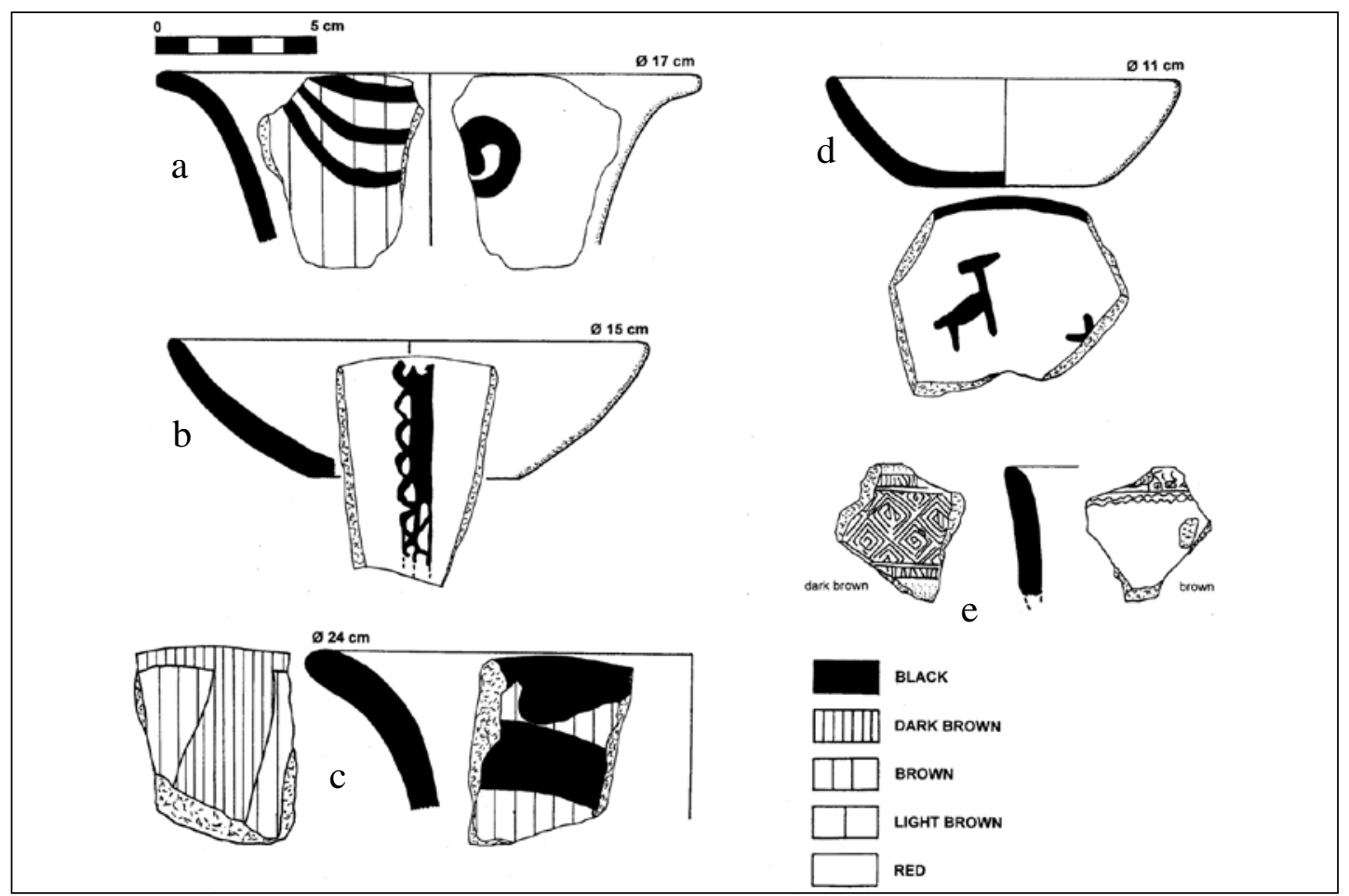

Figure 5. Local and exotic sherds found from Paria la Vieja.

Fragmentos de cerámica locales y exóticas encontrados en Paria la Vieja.

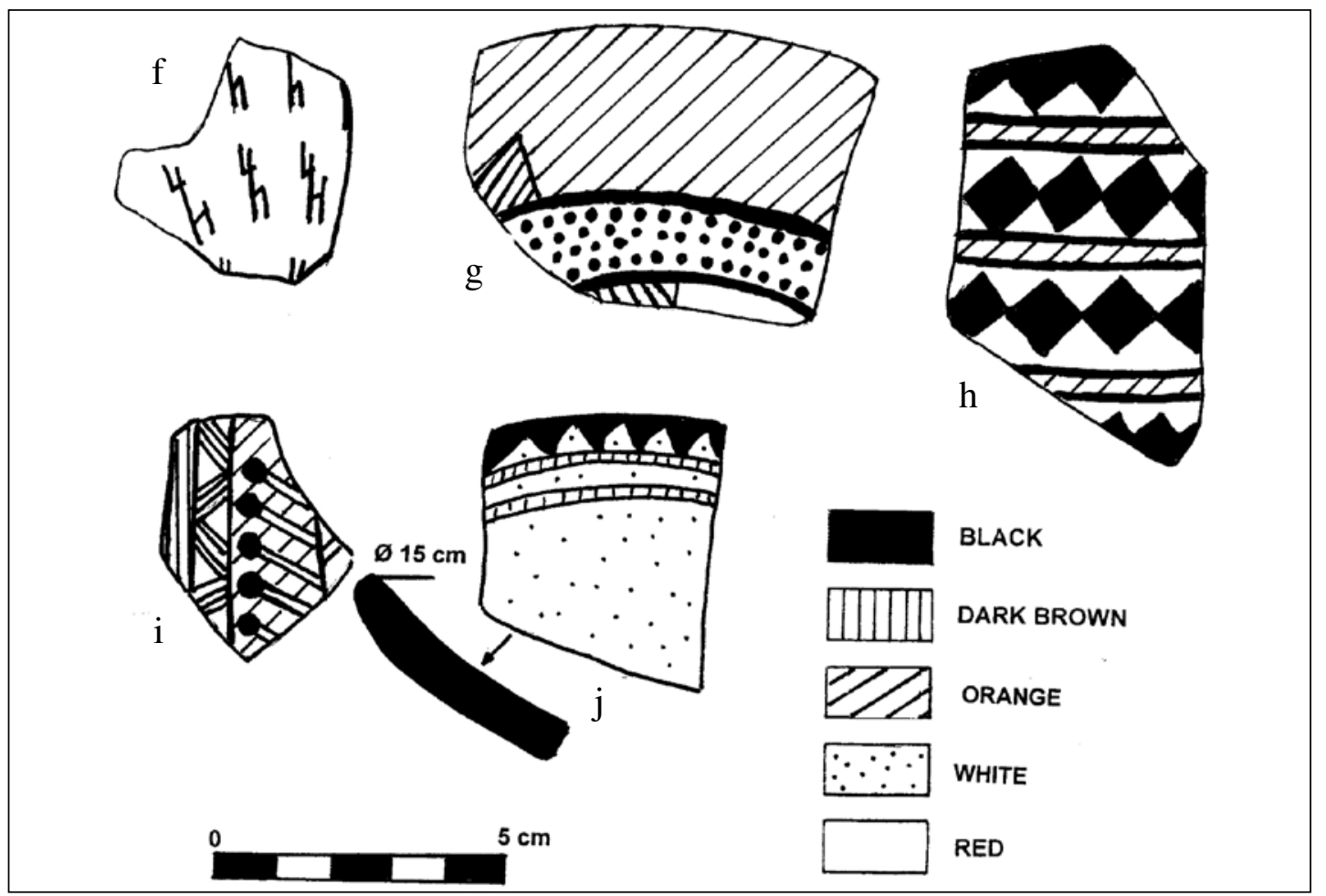

Figure 6. Inka Regional and Cuzco-style sherds from Paria la Vieja.

Estilos Inka cusqueño, Inka Regional y de Paria la Vieja. 
During the sampling also some stone artifacts, such as hoes and arrowheads were found as well as little white shell pearls. Some of those are quite similar as documented earlier by the team of Condarco (Condarco et al. 2002).

\section{Conclusion}

We may conclude that the earlier identification of Paria la Vieja, as proposed by Hermann Trimborn and the team of Carola Condarco, is correct. Comparing to the archaeological evidence of Anocariri site, proposed to be Paria la Vieja by John Hyslop, our site is three times bigger (35 ha vs 100 ha). Furthermore, the ceramic assemblage of our site in Pulupampa is predominantly composed of the Inka and the Regional Inka varieties unlike Anocariri, and finally, new evidence published in this report demonstrates that our site is the only one that has a huge concentration of storehouses. As far as we know, only Hatun Jauja of the primary provincial administrative centers of Tawantinsuyu has more storehouses than our site.

In addition, earlier we have observed in Chuquisaca (field observation in 1993-1994) that the cabeceras of Yampara province were generally ca. 20 - 35 hectares of their size. Comparing to these, Anocariri would be comparable in size to ordinary cabecera. This is also quite in accordance with our results in Caquiaviri, where the biggest site after the capital itself did not exceed 20 hectares (Pärssinen 2005). Nevertheless, a settlement area of ca. three times bigger than Anocariri means a qualitative jump in settlement hierarchy (see, Isbell and Schreiber 1978:149-170; Pärssinen 2005:8995), and thus, Pulupampa site can be classified in higher category.

From the point of view of historical evidence, we may add that unlike Anocariri, Pulupampa certainly belongs to the Paria quarter of Sora province. Pulupampa is also near enough to the lands of Tapacarí and Capinata in the east, which confirm its position one or one and a half league of distance of the territories of those two main towns. However, if Anocariri is the same as Apacomire of Caracollo, the distance from there to Pulupampa site is about one leagues less than expected ${ }^{4}$, but, on the other hand, the distance between the Lake Uru Uru and our site in Pulupampa is exactly the five leagues as also mentioned in the ceque list. In sum, we have no doubt that the Pulupampa site is ancient Paria.

Comparing Paria la Vieja to other first order provincial centers we have already noted, that it has the second biggest amount of storage silos. We cannot say much about the entire size of the Inka settlements of Quito, Tumipampa, Cajamarca or Hatun Colla because the Colonial and Republican habitational activities have destroyed our evidences. Nevertheless, we have more evidence from Huánuco, Jauja and Pumpu, because of better conservation of the Inka settlement sites. Calculating of the published map of Huánuco Pampa (Morris and von Hagen 1993:164-165), its size seems to be twice as big as Paria la Vieja. Nevertheless, according to D'Altroy (1992:106) and Matos Mendieta (1994:203) Hatun Jauja was only about 70 ha (ceramic evidence) and Pumpu ca. 76 ha (architectonic evidence). However, to these sizes we must add that in Jauja the storage areas were not included in the estimation and in Pumpu the main plaza and other open spaces were set apart from the calculation. Thus, both of them seem to be basically the same size as Paria, about 100 hectares, if calculated in comparable manner.

Finally, the team of Carola Condarco argues, that Paria la Vieja was founded in Late Intermediate Period and that it grew gradually. They establish their argument on the fact that local ceramics were found. We cannot reject this argument totally, because we do not have any radiocarbon evidence. However, historical evidence analyzed by Mercedes del Río (1997) indicates that Paria was founded by the Inkas on the main Inka road and that the ancient capital of Sora was Sora Sora, a settlement situated some 40 kilometers to the south of Paria. Furthermore, it was even testified that in the Inka time supreme chiefs of Paria were buried in the chullpas of Sora Sora (Del Río 1998:106-107). Taking this information in account, we consider it as most likely that Paria la Vieja was really founded by the Inkas. The ceramic evidence of local Sora (5\%) and Black-on-Red (20\%) vessels can be explained by the fact that also in many other administrative centers earlier local tradition continued alongside the new and massive Inka ceramic production, even though ancient settlements may have been resettled on the new location by the Inkas (e.g. D'Altroy et al. 2000:21; Pärssinen 1997:45-53; Pärssinen and Siiriäinen 1997:255-266). However, more archaeological investigation would be needed to confirm our supposition derived from historical sources. 
Acknowledgements: The investigations in Paria were funded by the University of Helsinki. In Bolivia the research was authorized by the Unidad Nacional de Arqueología de Bolivia. We wish to acknowledge especially the support and help of Lic. Javier Escalante, the director of the UNAR. The research formed a part of the project "Formations and transformations of ethnic identities in the South Central Andes, AD 700-1825", realized under auspice of CEISAL (Consejo Europeo de Investigaciones Sociales de América Latina).

\section{References Cited}

Alconini, S.

2004 The southeastern Inka frontier against the Chiriguanos: structure and dynamics of the Inka imperial borderlands. Latin American Antiquity 15:389-418.

Anonymous

1593 Los moxones e limites de las tierras que dio el ynga Guayna Capa a los yndios soras de Paria la viexa. Transcripted by J. V. Murra, Original in: Composiciones de tierras, Archivo Histórico de Cochabamba, Bolivia.

Ayavire y Velasco, F., P. Soto, A. Chuquivil, H. Soto, H. Hachacata, P. Cunaca, F. Vilca, C. Cuyo, and M. de Chaqui 1969 [1582] El Memorial de Charcas. Edited by W. Espinoza Soriano. Cantuta, Revista de la Universidad de Educación, No.4, Lima. Separata.

Barragán Vargas, M.E.

2001 La Historia Temprana de Tarija. Gráfica Offset "Kokito", Tarija.

Bauer, B.S.

2000 El Espacio Sagrado de los Incas. El Sistema de Ceques del Cuzco. Archivos de Historia Andina 33, Centro de Estudios Regionales Andinos "Bartolomé de Las Casas", Cuzco.

Bouysse-Cassagne, Th.

1986 Urco and Uma: Aymara concepts of space. In Anthropological History of Andean Polities, edited by J.V Murra, N. Wachtel and J. Revel, pp. 201-227. Cambridge University Press, Cambridge.

Céspedes Paz, R.

1982 La arqueología en el área de Pocona. Cuadernos de Investigación, Serie Arqueología No. 1, pp. 89-99, Universidad Mayor de San Simón - Instituto de Investigaciones Antropológicas, Cochabamba.

Cieza de León, P. de

1986a [1553] Crónica del Perú. Primera parte. Segunda edición corregida. Pontificia Universidad Católica del Perú, Lima.

1986b [1553] Crónica del Perú. Segunda parte. Segunda edición corregida. Pontificia Universidad Católica del Perú, Lima.

Condarco Castellón, C., E. Huarachi Mamani and M.J. Vargas Rosquellas

2002 Tras las huellas del Tambo Real de Paria. Investigaciones Regionales No. 5, Fundación PIEB, Editorial Offset Boliviana Ltda, La Paz.

Covey, R.A.

2000 Inka Administration of the Far South Coast of Peru. Latin American Antiquity 11:119-138.

D'Altroy, T.N.

1992 Provincial Power in the Inka Empire. Smithsonian Institution Press, Washington, DC.
2002 The Incas. Blackwell Publisher Inc. Malden, Massachusetts.

D'Altroy, T.N. and R.L. Bishop

1990 The provincial organization of Inka ceramic production. American Antiquity 55:120-138.

D'Altroy, T.N., A.M. Lorandi, V.I. Williams, M. Calderari, Ch.A. Hastorf, E. DeMarrais and M.B. Hagstrum

2000 Inka rule in the Northern Calchaquí Valley, Argentina. Journal of Field Archaeology 27:1-26.

Del Río, M.

1997 Relaciones Interétnicas y Control de Recursos entre los Aymaras del Macizo de Charcas. Los Soras del Repartimiento de Paria: Estrategias de Acceso a Tierras. Siglos XVI-XVII. Doctoral Dissertation, Universidad de Buenos Aires, Buenos Aires.

1998 Ancestros, guerras y migraciones. Reflexiones en torno al origen y vinculaciones étnicas de los Soras de la provincia de Paria. Historias... Revista de la Coordinadora de Historia 2:93-12. Número especial en homenaje a Teresa Gisbert, La Paz.

Gasparini, G. and L. Margolis

1980 Inca Architecture. Traduced by P.J. Lyon. Indiana University Press, Bloomington.

Guaman Poma de Ayala, F.

1987 [1615] Nueva Corónica y Buen Gobierno. Edited by J.V. Murra, R. Adorno and J.L. Urioste. Crónicas de América 29a-c, Historia 16, Madrid.

Hyslop, J.

1984 The Inka Road System. Academic Press, INC, Orlando \& London.

1990 Inka Settlement Planning. University of Texas Press, Austin.

Isbell, W. and K. Schreiber

1978 Was Huari a State? American Antiquity 43:149-170.

Jenkins, D.

2001 A network analysis of Inka Roads, administrative centers, and storage facilities. Ethnohistory 48(4):655-687.

Julien, C.J.

1983 Hatunqolla: A View of Inca Rule from the Lake Titicaca Region. University of California Publications in Anthropology, Vol.15, University of California Press, Berkeley \& Los Angeles.

1993 Finding a fit: Archaeology and ethnohistory of the Incas. In Provincial Inca. Archaeological and Etnohistorical Assessment of the Impact of the Inca State, pp. 177-233, edited by M.A. Malpass. University of Iowa Press, Iowa City.

Korpisaari A. and M. Pärssinen, editors

2005 Pariti: Isla, Misterio y Poder. El Tesoro Cerámico de la Cultura Tiwanaku. República de Bolivia y República de Finlandia, Producciones CIMA, La Paz. 
La Lone, M.B. and D.E. La Lone

1987 The Inka State in the Southern Highlands: State administrative and production enclaves. Ethnohistory 34(1):47-62.

Matos Mendieta, R.

1994 Pumpu: Centro Administrativo Inka de la Puna de Junín. Editorial Horizonte, B.C.R. Fondo editorial, Taraxacum, Lima.

Morales, A.

1977 Repartimiento de Tierras por el Inca Huayna Capac (Testimonio de un Documento de 1556). Universidad de San Simón, Departamento de Arqueología, Museo Arqueológico. Cochabamba.

Morris, C.

1981 Tecnología y organización inca del almacenamiento de víveres en la sierra. In La Tecnología en el Mundo Andino, tomo I, pp. 327-375, edited by H. Lechtman \& A.M. Soldi. Universidad Nacional Autónoma de México, México.

Morris, C. and D.E. Thompson

1974 Huánuco Viejo: An Inca administrative center. In The Rise and Fall of Civilizations, edited by C.C. LambergKarlovsky \& J.A. Sabloff. Cummings Publishing Company, Menlo Park, California.

1985 Huánuco Pampa - An Inca City and its Hinterland. Thames and Hudson, London.

Morris, C. and A. von Hagen

1993 The Inka Empire and its Andean Origins. American Museum of Natural History, Abbeville Press Publishers, New York.

Murra, J. V., R. Adorno and J. L. Urioste

1987 Notas aclaratorias. In F. Guaman Poma de Ayala Nueva Corónica y Buen Gobierno. Crónicas de América 29c, pp. 1317-1379. Historia 16, Madrid.

Pachacuti Yamqui Salcamaygua, J. de Santa Cruz

1993 [1613] Relación de las Antiguedades deste Reyno del Pirú. Edited by P. Duviols \& C. Itier. Institut Français d'Études Andines, Lima.

Pärssinen, $M$.

1992 Tawantinsuyu. The Inca State and Its Political Organization. Studia Historica 43, Societas Historica Finlandiae, Helsinki.

1997 Investigaciones arqueológicas con ayuda de fuentes históricas: Experiencias en Cajamarca, Pacasa y Yampará. In Saberes y Memorias en los Andes. In Memoriam Thierry Saignes, edited by Th. Bouysse-Cassagne, pp. 41-58. Institut des Hautes Études de l'Amérique Latine, Paris - Institut Francais d'Études Andines, Lima.

2005 Caquiaviri y la Provincia de Pacasa (Bolivia), Desde el Alto-Formativo hasta la Conquista Española (1-1533). Maestría en Historias Andinas y Amazónicas (UMSA), Colegio Nacional de Historiadores de Bolivia \& CIMA Editores, La Paz.

Pärssinen, M. and J. Kiviharju

2004 Textos Andinos. Corpus de Textos Khipu Incaicos y Coloniales. Tomo I, Acta Ibero-Americana Fennica, Series Hispano-Americana 6, Instituto Iberoamericano de Finlandia \& Departamento de Filología Española I, Facultad de Filología, Universidad Complutense de Madrid, Madrid.
Pärssinen, M. and A. Siiriäinen

1998 Cuzcotoro and the Inka fortification system in Chuquisaca, Bolivia. Baessler-Archiv, Neue Folge 46, 135 164, Berlin.

2003 Andes Orientales y Amazonía Occidental. Ensayos entre la Historia y la Arqueología de Bolivia, Brasil y Perú. Maestría en Historias Andinas y Amazónicas (UMSA), Colegio Nacional de Historiadores de Bolivia \& CIMA Editores, La Paz.

Pereira Herrera, D.

1982 Kharalaus Pampa: Tambo incaico en Quillacollo. Cuadernos de Investigación, Serie Arqueología No. 1, pp. 100-104, Universidad Mayor de San Simón - Instituto de Investigaciones Antropológicas, Cochabamba.

Pizarro, F.

1535 Titulo de la encomienda de Paria y Urcos en Pedro del Barco por Francisco Pizarro, Cuzco 1-VIII-1535. Manuscript, Justicia 429, Archivo General de Indias, Seville.

1540 Titulo de la encomienda de Francisco Pizarro a Alonso Manjarrez, Cuzco 22-I-1540. Manuscript, Pieza 2, Ramo 1, No.5, Justicia 1125, Archivo General de Indias, Seville.

Raffino, R.

1993 Inka: Arqueología, Historia y Urbanismo del Altiplano Andino. Corregidor, Buenos Aires.

Segovia, B. de

1943 [1552] Destrucción del Perú (Atribuida a Cristóbal de Molina, el Almagrista). Los Pequeños Grandes Libros de Historia Americana, serie I, Tomo IV, Lima.

Siiriäinen, A. and M. Pärssinen

2003 The Amazonian interest of the Inca State (Tawantinsuyu). Baessler-Archiv, Neue Folge 49:45-78.

Snead, J.E.

1992 Imperial infrastructure and the Inka State storage system. In Inka Storage Systems, edited by T.Y. LeVine, pp.62-106. University of Oklahoma Press, Norman \& London.

Trimborn, $\mathrm{H}$.

1967 Archäologische studien in den kordilleren boliviens III. Baessler-Archiv, Neue Folge - Beiheft 5.

Tschopik, M.H.

1946 Some Notes on the Archaeology of the Department of Puno, Peru. Papers of the Peabody Museum of American Archaeology and Ethnology, Harvard University, Vol. xxvii, No. 3, Cambridge, Mass.

Vaca de Castro, C.

1908 [1543] Ordenanzas de tambos. Distancias de unos a otros, modo de cargar los indios y obligaciones de las justicias respectivas hechas en la ciudad del Cuzco en 31 de mayo de 1543. Revista Histórica Tomo III:427-491.

Wachtel, N.

1982 The mitimas of the Cochabamba Valley: The colonization policy of Huayna Capac. In The Inca and Aztec States, edited by G.A. Collier, R.I. Rosaldo and J.D. Wirth, pp. 199-236. Academic Press, New York.

Zuidema, R.T.

1995 El Sistema de Ceques del Cuzco: La Organización Social de la Capital de los Incas. Pontificia Universidad Católica del Perú, Fondo editorial, Lima. 


\section{Notes}

1 Nevertheless, there was also another road in the north that ran from Tapacarí to Quilca (Del Rio 1997:38).

2 It is interesting that immediately after Almagro left Cuzco, Pizarro gave Paria for his friend Pedro del Barco as an encomienda grant, see Pizarro 1535: fols. 70v-72r.

3 We have observed many times during our research in Bolivian altiplano, that truck owners are still searching ancient settlements in order to transport and sell stones from ancient buildings.

4 According to Hyslop (1984), Anocariri is situated ca. 8 kilometres to the west-northwest of the present Paria that would make about two leagues of Paria la Vieja. Nevertheless, according to our own estimation Anocariri is situated only three kilometres from the present Paria. 